\title{
Decoupling Elasticity Analysis on Low Carbon Agriculture in Shanghai
}

\author{
Zhenyu Zhang \\ College of Economics \& Management, Shanghai Ocean University, China
}

Copyright $(2016$ by authors, all rights reserved. Authors agree that this article remains permanently open access under the terms of the Creative Commons Attribution License 4.0 International License

\begin{abstract}
This paper discusses the potential of emission abatement in Shanghai in order to achieve low-carbon agriculture in suburbs. The total agricultural carbon emissions (hereinafter to be referred as agro-emission), net agro-emissions, taking into consideration of agricultural activity's contribution to absorb emission, and per capita agro-emission in 2013 are calculated to demonstrate the distribution of emissions cross nine suburbs in Shanghai. The calculation results suggest that suburbs of Pudong, Chongming and Fengxian are the focus for reducing the total agro-emission and net agro-emission, while Fengxian, Jinshan and Songjiang are the top three suburbs need to cut back per capita agro-emission. The structure and characteristics of agricultural production for 1993-2013 in Shanghai are discussed to explain the increase in agricultural carbon emission and possible ways for abatement. The decomposition of emission source and structure also implies that improving energy efficiency and reducing the amount of energy consumption will be the direction for further emission abatement in Shanghai agricultural development. The decoupling elasticity is computed for 1994-2013 using 1992 as base year, and agricultural economic development is found to be weakly decoupled with agro-emission growth in Shanghai. Further, an Environmental Kuznet type curve is estimated to examine the shape of relationship between agro-emission growth and agricultural development using software Stata13.0 The data information on agricultural activities in all suburbs of for 1993-2013 have been used for running the regression, and estimation suggests that agro-emission does have inverse-U shape relationship with agricultural development in Shanghai.
\end{abstract}

Keywords Agricultural Emission, Decoupling Elasticity, Abatement Potential, Environmental Kuznet Curve, Shanghai Suburb, Low-carbon Economy

\section{Introduction}

Low carbon economy is the strategy that human being coping with global climate change. Heavy industry is always the focus for further emission abatement for a long time, while the main greenhouse gas emissions that contribute to global climate change are carbon dioxide $\left(\mathrm{CO}_{2}\right)$, methane $\left(\mathrm{CH}_{4}\right)$, nitrogen oxide $\left(\mathrm{N}_{2} \mathrm{O}\right)$. In fact, $20 \%$ of carbon dioxide, $70 \%$ of methane, and $90 \%$ of nitrogen oxide comes from agricultural activities [1,2]. Even though, the sum of methane and nitrogen oxide is far less than carbon dioxide, but the global warming potential of $\mathrm{CH}_{4}$ and $\mathrm{N}_{2} \mathrm{O}$ is 25 times and 298 times of $\mathrm{CO}_{2}$ respectively[3]. According to World Bank database, $\mathrm{CH}_{4}$ and $\mathrm{N}_{2} \mathrm{O}$ from Chinese agriculture account for $35.9 \%$ and $75.4 \%$ of national methane and nitrous oxide emissions respectively in 2010. Agriculture plays double role in carbon emission and carbon sink, and becomes the second largest source of carbon emissions in China [4]. Agricultural carbon emissions mainly refer to $\mathrm{CO}_{2}, \mathrm{CH}_{4}$ and $\mathrm{N}_{2} \mathrm{O}$, as following combined as agro-emission.

Shanghai agricultural development is selected in this study, due to its economic importance in China. In 2013, Shanghai GDP ranks 12 th and its pure income per capita of rural resident ranks top consecutively for more than twenty years since 1995. While Shanghai's agricultural carbon intensity ranks $2^{\text {nd }}$ of all provinces in China in 2008 about $1.788 \mathrm{t} / \mathrm{hm}^{2}$ [5.6], its mean value of agricultural carbon emission performance ranks $10 \mathrm{t}^{\mathrm{h}}$ in the nation [7]. During the 12th five-year plan (2010-2015) in China, Shanghai is required to reduce total carbon emission by $18 \%$ by the end of 2015, which is higher than the national average goal, $16 \%$.

Examining on the sources of carbon emission generation from agricultural activities, such as energy consumption, agricultural inputs, irrigation and ranching, helps understanding how to improve and optimize agricultural production structure in Shanghai. This paper will discuss the potential of emission abatement and direction of low carbon economy development from the following aspects:(1)To compute the total agro-emissions, net agro-emissions and per capita agro-emission in 2013, using emission coefficients issued by IPCC[3], modified emission coefficients for ranching and rice paddy irrigation in Zhejiang province Huang and Mi [8], land emission coefficient, soil 
sequestration and crop photosynthesis for carbon absorption suggested by Qian [9] in Shanghai agriculture;(2)To discuss the distribution of agro-emissions cross nine suburbs and to find out the focus area for further emission abatement in Shanghai; (3)The agro-emission intensity for 1993-2013 is calculated to understand the contribution of agricultural economic development on agro-emission generation; (4)The geometric growth rate of total agro-emissions for 1993-2013 is calculated, and the different sources of agro-emission generation are examined for providing the direction of further emission abatement in Shanghai agriculture; (5) Examine the relationship between agricultural economic development and emission growth using the decoupling elasticity analysis[10,11] and empirical study of Environmental Kuznet model using software of Stata13.0 for estimation.

\section{Method and Data Source}

\subsection{Emission Coefficients}

The carbon emission generated in the process of agricultural development mainly comes from irrigation of rice paddy $\left(\mathrm{CH}_{4}\right)$, enteric fermentation $\left(\mathrm{CH}_{4}\right)$, the use of plastic cover, fertilizer and pesticide $\left(\mathrm{N}_{2} \mathrm{O}\right)$, emission from energy consumption $\left(\mathrm{CO}_{2}\right)$, such as electricity, diesel, etc. $\left(\mathrm{CO}_{2}\right)$, life cycle of animal waste and crops straw (not counted into this study due to the missing information of rice straw), cropland tittering $\left(\mathrm{CO}_{2}\right)$. The emission coefficient for different sources is shown in Table 1.

Shanghai has promoted several rounds of environmental protection action since 2000, the 5th action during 2012 and 2014 , the plan of environmental friendly agriculture aims at controlling total amount of pollution generated from agricultural activities, and developing ecological and circulates agriculture. In 2014, Shanghai plans to cut back Chemical Oxygen Demand and ammonia emission by $7 \%$ and $8 \%$ respectively, compared to the level of 2011, increase the usage rate of crop straw up to $85 \%$, also encourage for growing the green manure, and applying fertilizer after soil test. Since 2009, due to more scientific application of fertilizer, usage of fertilizer per cropland in Shanghai has been reduced greatly, about $522 \mathrm{~kg} / \mathrm{hm}^{2}$ [16], but much higher than national level, $346 \mathrm{~kg} / \mathrm{hm}^{2}$ [16]. The utilization rate of fertilizer in Shanghai is pretty low, only $35 \%$, far less than that of developed countries, about $50-60 \%$ [17]. Some of studies show that further emission abatement can be realized through changing the means of agricultural production, such as improving efficiency of fertilizer usage could reduce $\mathrm{N}_{2} \mathrm{O}$ emission [9], improvement on nutrient of ruminants could reduce $15-30 \%$ of $\mathrm{CH}_{4}$ emission per each meat cow(Dong et al 2008), promoting the intermittent irrigation could help to reduce $30 \%$ of $\mathrm{CH}_{4}$ emission per unit of rice paddy, and use of slow release fertilizer would help to cut $50-70 \%$ of $\mathrm{N}_{2} \mathrm{O}$ per unit of cropland [18]. The other methods for emission abatement include soil sequestration and crop photosynthesis.

Table 1. Emission coefficient and reference

\begin{tabular}{|c|c|c|c|}
\hline Emissions & Source & $\begin{array}{c}\text { Emission } \\
\text { coefficient } \\
\left(\mathrm{CO}_{2} \text { eq }\right)\end{array}$ & Reference \\
\hline $\mathrm{CO}_{2}$ & $\begin{array}{l}\text { electricity used } \\
\text { in agriculture }\end{array}$ & $\begin{array}{l}\text { 0.8244ton/ } \\
\text { MWH }\end{array}$ & $\begin{array}{l}\text { Climate Change of } \\
\text { National } \\
\text { Development and } \\
\text { Reform } \\
\text { Committee (2012) } \\
{[12]}\end{array}$ \\
\hline $\mathrm{CO}_{2}$ & $\begin{array}{c}\text { diesel } \\
\text { consumption } \\
\text { for agriculture } \\
\end{array}$ & 0.5927 ton/ton & IPCC (2006)[3] \\
\hline $\mathrm{CO}_{2}$ & $\begin{array}{c}\text { Land tilter } \\
\text { ( farmland } \\
\text { measured by } \\
\text { the end of year) }\end{array}$ & $1.7500 \mathrm{ton} / \mathrm{hm}^{2}$ & $\begin{array}{l}\text { Qian (2011) [9] } \\
\text { Li et al (2011) [5] }\end{array}$ \\
\hline $\mathrm{CH}_{4}$ & $\begin{array}{l}\text { Rice paddy } \\
\text { ( measured in } \\
\text { cropland area) }\end{array}$ & 0.2660 ton $/ \mathrm{hm}^{2}$ & Qian (2011) [9] \\
\hline $\mathrm{CH}_{4}$ & $\begin{array}{l}\text { Livestock of } \\
\text { Cow (Enteric } \\
\text { fermentation, } \\
\text { manure } \\
\text { management ) }\end{array}$ & $\begin{array}{l}\text { 1.5572ton } \\
\text { /head }\end{array}$ & $\begin{array}{l}\operatorname{IPCC}(2006)[3] \text {, } \\
\text { Huang and } \mathrm{Mi} \\
(2011)[8]\end{array}$ \\
\hline $\mathrm{CH}_{4}$ & $\begin{array}{l}\text { Livestock of } \\
\text { hog (manure) }\end{array}$ & 0.1025 ton $/$ head & $\begin{array}{l}\text { IPCC(2006)[3] } \\
\text { Huang and Mi } \\
\text { (2011)[8] } \\
\text { Zhang et al } \\
\text { (1999)[13] }\end{array}$ \\
\hline $\mathrm{CH}_{4}$ & $\begin{array}{l}\text { Livestock of } \\
\text { poultry } \\
\text { (manure) }\end{array}$ & $\begin{array}{l}0.0004 \\
\text { ton/head }\end{array}$ & $\begin{array}{l}\text { IPCC(2006)[3], } \\
\text { Huang and Mi } \\
\text { (2011)[8], Zhang } \\
\text { et al (1999) [13] }\end{array}$ \\
\hline $\mathrm{N}_{2} \mathrm{O}$ & pesticide & 4.9341 ton/ton & $\begin{array}{l}\text { West and Marland } \\
(2002)[14]\end{array}$ \\
\hline $\mathrm{N}_{2} \mathrm{O}$ & fertilizer & 0.8956 ton $/$ ton & $\begin{array}{l}\text { West and Marland } \\
(2002)[14]\end{array}$ \\
\hline $\mathrm{N}_{2} \mathrm{O}$ & Plastic cover & 5.18 ton $/$ ton & $\begin{array}{l}\text { Institution of } \\
\text { Agricultural } \\
\text { resource and } \\
\text { environmental } \\
\text { ecology of Nanjing } \\
\text { Agricultural } \\
\text { University (2010) } \\
\text { [15] }\end{array}$ \\
\hline
\end{tabular}

The rice and wheat are selected in the study to be the representative crops grown in suburbs of Shanghai, since either total production of, or the growing area of both crops account for over 90\% in Shanghai [19]. The study of Qian [9] shows that the carbon absorption coefficients of rice and wheat are 0.987 and 0.877 respectively. The emission abatement from agricultural activity mainly refers to emission abatement due to crops photosynthesis of rice and wheat in Shanghai.

\subsection{Data Source}

There are nine suburb areas involving agricultural production in Shanghai: Minghang (MIN), Baoshan(BAO), 
Jiading(JIA), Songjiang (SON), Qingpu(QIN), Jinshan (JIN), Chongming (CHO), Fengxian (FEN), and Pudong (PU).

The agro-carbon emissions are mainly generated from rice paddy irrigation, enteric fermentation of dairy cow, fermentation of animal waste (cow, hog and poultry), and land tillage and energy consumption for agricultural activities. The natural sources of emission absorption come from crop photosynthesis, carbon sequestration through soil and forestry.

The information on agricultural activity in Shanghai suburb mainly comes from the statistical yearbook of Shanghai suburb for the year of 1993-2013 [19], the information on the use of agricultural inputs, such as fertilizer, plastic cover, and pesticide, comes from the agricultural statistics of New China' 60 years [20]. The emission coefficient of electricity consumption for agricultural activities refers to the emission factor for regional power grid in China, issued by the Climate Department of National development and reform in 2014, while the coefficient of electricity emission in East China has been chosen for the computation [12]. We use data of agricultural activities in 2013 to compute the carbon emissions generated from nine suburbs in Shanghai [19].

\subsection{Decoupling Elasticity}

Table 2. Categories of Decoupling Status

\begin{tabular}{|c|c|c|c|c|}
\hline Status & $\begin{array}{l}\text { Decoupling } \\
\text { status }\end{array}$ & $\begin{array}{c}\text { Emission } \\
\text { growth }\end{array}$ & $\begin{array}{c}\text { Agricultural } \\
\text { GDP } \\
\text { growth }\end{array}$ & $\begin{array}{l}\text { Decoupling } \\
\text { elasticity }\end{array}$ \\
\hline \multirow{3}{*}{ Decoupled } & $\begin{array}{c}\text { Weak } \\
\text { decoupling }\end{array}$ & $\mathrm{CR}>0$ & $E R>0$ & $0 \leq \varepsilon \leq 0.8$ \\
\hline & $\begin{array}{c}\text { Strong } \\
\text { decoupling }\end{array}$ & $\mathrm{CR}<0$ & $E R>0$ & $\varepsilon<0$ \\
\hline & $\begin{array}{l}\text { Recessive } \\
\text { decoupling }\end{array}$ & $\mathrm{CR}<0$ & $\mathrm{ER}<0$ & $\varepsilon>1.2$ \\
\hline \multirow{3}{*}{$\begin{array}{l}\text { Negative } \\
\text { decoupled }\end{array}$} & $\begin{array}{l}\text { Expansive } \\
\text { negative } \\
\text { decoupling }\end{array}$ & $\mathrm{CR}>0$ & $E R>0$ & $\varepsilon>1.2$ \\
\hline & $\begin{array}{c}\text { Strong } \\
\text { negative } \\
\text { decoupling }\end{array}$ & $\mathrm{CR}>0$ & $\mathrm{ER}<0$ & $\varepsilon<0$ \\
\hline & $\begin{array}{c}\text { Weak } \\
\text { negative } \\
\text { decoupling }\end{array}$ & $\mathrm{CR}<0$ & $\mathrm{ER}<0$ & $0 \leq \varepsilon \leq 0.8$ \\
\hline \multirow{2}{*}{ Coupling } & $\begin{array}{l}\text { Expansive } \\
\text { coupling }\end{array}$ & $\mathrm{CR}>0$ & $E R>0$ & \\
\hline & $\begin{array}{l}\text { Recessive } \\
\text { coupling }\end{array}$ & $\mathrm{CR}<0$ & $\mathrm{ER}<0$ & $0.8 \leq \varepsilon \leq 1.2$ \\
\hline
\end{tabular}

Using the method proposed by Tapio [10] and applied in agricultural emission in Hubei province by Yuan et al [11], decoupling elasticity analysis in this study is defined as following:

$$
\varepsilon=\frac{\Delta A g C / A g C_{n}}{\triangle A g G D P / A g G D P_{n}}=\frac{C R_{n}}{E R_{n}}
$$

where $\varepsilon$ is the decoupling elasticity, to measure the decoupling relationship between emission and economic development; $\mathrm{CR}$ is the carbon emission growth rate; $\mathrm{AgC}_{\mathrm{n}}$ is the total agro-emission in $\mathrm{n}^{\text {th }}$ year, $\Delta \mathrm{AgC}$ is the increased emission of $\mathrm{n}^{\text {th }}$ year from previous year; ER is the economic growth rate; $\operatorname{AgGDP}_{n}$ is the agricultural GDP of $\mathrm{n}^{\text {th }}$ year, $\Delta$ AgGDP is the increased agricultural GDP of $n^{\text {th }}$ year from the previous year. According to the value of elasticity, economic growth rate and emission growth rate, decoupling status can be classified into eight categories, seen in Table 2 .

\subsection{EKC Model}

To examine the relationship shape between economic growth and environment, a EKC model is estimated, while agro-emission is used as an indicator for environmental quality, and agricultural GDP is used as a measure for economic growth of agriculture. The regression is set up as following:

$$
A g C_{i j}=\beta_{0}+\beta_{1} A g G D P_{i j}+\beta_{2}\left(A g G D P_{i j}\right)^{2}+e_{i j}
$$

where $\mathrm{AgCij}$ is the total agro-emission generated from $\mathrm{j}^{\text {th }}$ suburb $(j=1,2, \ldots 9)$ at $i^{\text {th }}$ year $(i=1993, \ldots .2013)$ in Shanghai, $\operatorname{AgGDP}_{\mathrm{ij}}$ is the agricultural GDP of $\mathrm{j}^{\text {th }}$ suburb at $\mathrm{i}^{\text {th }}$ year in Shanghai, $e_{i j}$ is the random error for $j^{\text {th }}$ suburb at $i^{\text {th }}$ year 's observation, assuming other than economic factor has no impact on generation of agricultural emission. If $\beta_{1}=0$ $\operatorname{and} \beta_{2}=0$, it suggests that economic development in agriculture is not associated with emission generation, and both are strongly decoupled; If $\beta_{1} \neq 0$ and $\beta_{2}=0$, it suggests that agro-emission and agricultural development has linear relationship, and agro-emission is strongly coupled with economic development; if $\beta_{1} \neq 0$ and $\beta_{2} \neq 0$, it suggests that agro-emission and economic growth has inverse-U shape relationship, and both are weakly decoupled.

\section{Analysis}

\subsection{Total Emission, Net Emission and Per Capita Emission}

Total emission, net emission and per capita emission for all nine suburbs are calculated using coefficients summarized in Table 1 . The selected agricultural activities that contribute to carbon emission include the use of electricity, diesel, pesticide, fertilizer, plastic for agricultural production, rice paddy field, cow ranching, hog and poultry production. Based on the emission computation, the carbon emissions generated from suburb of $\mathrm{PU}, \mathrm{CHO}$ and FEN are found to be in top 3, and sum of three districts accounts for $58.27 \%$ of total agro-emissions in Shanghai. More details about the distribution of total emission for nine suburbs are shown in Figure 1. The agricultural added values in three suburbs account for over $55 \%$ of that in nine suburbs, implying that $\mathrm{PU}, \mathrm{CHO}$ and FEN play important role in agricultural activities among all suburbs; also they will be the focus for further total emission abatement in Shanghai agriculture. 


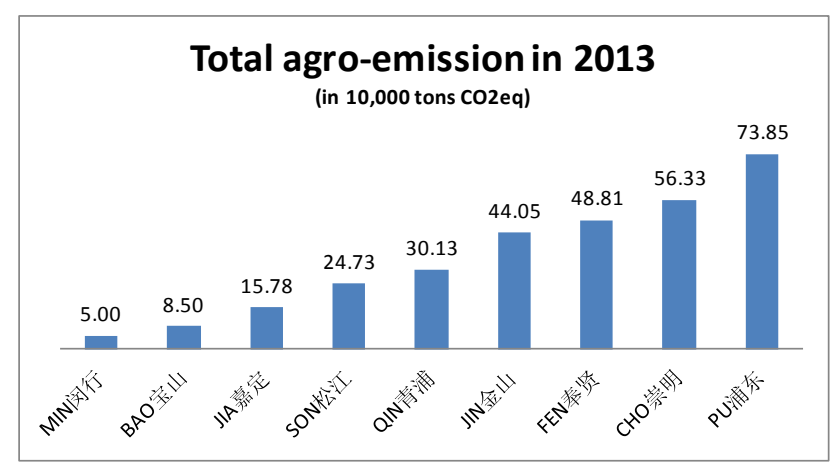

Figure 1. Distribution of total agro-emissions cross suburb in 2013

In addition to generate the carbon emission, agricultural activates also contribute to reduce the emission through soil sequestration, crop photosynthesis. Since each suburb is different in agricultural production structure and size of cropland, the capability of emission abatement varies cross different suburb. Taken into consideration both of emission and abatement, the net carbon emissions generated from nine suburbs rank from high to low as PU, CHO, FEN, JIN, QIN, JIA, BAO and MIN. The distribution of top three highest net emissions has same pattern as that of total emission does, except in a slightly different order. While $\mathrm{CHO}$ ranks $3^{\text {rd }}$ in net emission, it suggests that agriculture in $\mathrm{CHO}$ does good job in emission sequestration. Still, the areas of PU, CHO, and FEN are the main districts for further abatement and developing low-carbon agricultural economics in Shanghai.

The mean of emission per capita in 2013 is about 1.08 ton of carbon dioxide equivalent in Shanghai and details for each suburb are shown in Figure 2. The district of BAO, PU and JIA are the only three suburbs having per capita emissions lower than the average level. Per capita emission in suburb of FEN, JIN, SON ranks top three, which is 1.71, 1.39 , and 1.36 tons respectively. Especially for JIN and SON, the total emission of which ranks 5th and 6th respectively, but per capita emission of which ranks $2^{\text {nd }}$ and $3^{\text {rd }}$ respectively, implying that the labor efficiency in these two suburbs needs to be improved.

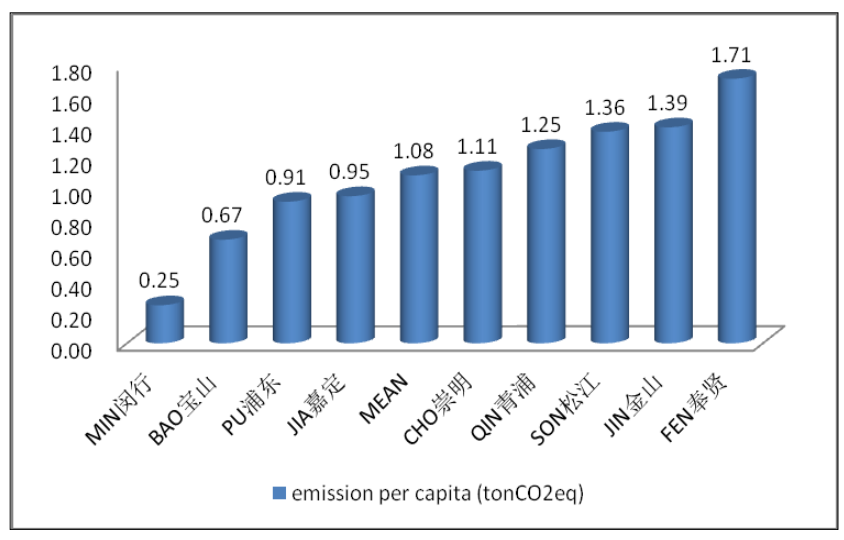

Figure 2. Emission per capita for each suburb in 2013

\subsection{Emission Intensity}

The emission intensity is measured in tons of carbon dioxide equivalent per 10,000RMB of agricultural GDP. Overall, the intensity is decreasing from 1992 to 2013, which was about 2.5 tons in 1992, dropped dramatically to 1.1 tons in 1997, went up a little in 1998, then kept going down to 0.85 tons in 2001, and varied within $15 \%$ around 1 tons for 2001-2013. The trend of emission intensity from 1992 to 2013 is shown in Figure 3.

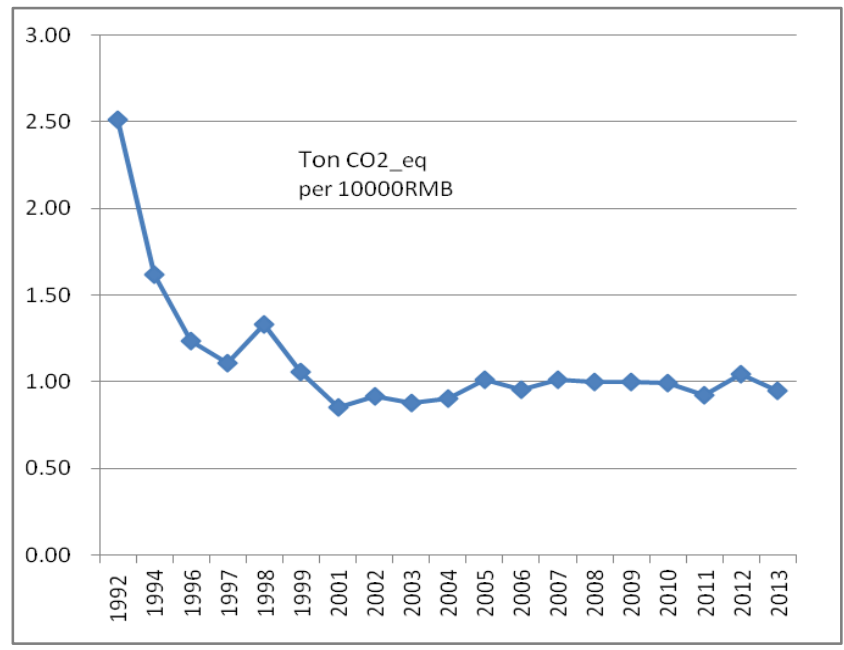

Figure 3. Emission intensity for $1992-2013$ in Shanghai

\subsection{Emission Structure and Characteristics over Time}

For the time period of 1992 - 2013, total carbon emission generated from agricultural activities in Shanghai is increasing in general, the annual geometric growth rate of emission is $9.1 \%$. The sources of carbon emission mainly come from energy consumption, use of agricultural inputs, irrigation for rice paddy, enteric fermentation of dairy cow and manure management. From 1992 to 2013, The growth rate of agro-emission due to the use of electricity and diesel consumption in agriculture is $45.8 \%$, the growth rate of agro-emission due to the use of agricultural inputs, irrigation on rice paddy and fermentation of ranching is $1.4 \%, 4.9$ and $4.7 \%$ respectively. The pattern of growth rate of total agro-emission for 1992-2013 and decomposition of total agro-emission from different sources are displayed in Figure 4. Noticing that growth of total agro-emission is moving at same direction as that of emissions due to agro-energy consumption. The Pearson correlation test between total agro-emission growth and growth of emissions generated from agro-energy consumption has been run, while the correlation coefficient is 0.87 , which is statistically significant at significant level of $1 \%$.

And correlations between total agro-emissions and emissions generated from the use of agro-inputs, irrigation of rice paddy and ranching are not statistically significant. On average, the agro-emissions due to energy consumption use of agro-inputs, rice paddy irrigation, and ranching 
accounts for $54 \%, 17 \%, 18 \%$ and $11 \%$ of total agro-emissions respectively. The proportion of total emission generated from energy consumption has dramatically increased from $14 \%$ in 1992 to $78 \%$ in 2011 , and decreased to $70 \%$ in 2013 ; the proportion of total emission generated from the use of agricultural inputs has decreased from $42 \%$ in 1992 to $26 \%$ in 1997 , went up to $34 \%$ in 1998 , and kept decreasing continuously to $7 \%$ in 2013; the proportion of total emission generated from plantation reduced from $28 \%$ in 1992 to $15 \%$ in 2013 ; the proportion of total emission generated from ranching decreased from $17 \%$ in 1992 to $9 \%$ in 2013 . It indicates that Shanghai suburb has made great improvement on emission abatement through reducing the use of agricultural inputs, and also there is much to improve in the efficiency and usage level of energy consumption for further emission reduction.

\subsection{Decoupling Elasticity}

Table 3. Decoupling relationship between Agro-emission and Agricultural GDP in Shanghai

\begin{tabular}{|c|c|c|c|c|}
\hline YEAR & $\begin{array}{c}\text { Growth rate of } \\
\text { agro-emission } \\
(\%)\end{array}$ & $\begin{array}{c}\text { Growth rate } \\
\text { of agro-GDP } \\
(\%)\end{array}$ & Elasticity & Status \\
\hline 1994 & 14.10 & 76.67 & 0.18 & $\begin{array}{c}\text { Weak } \\
\text { decoupling }\end{array}$ \\
\hline 1996 & 24.45 & 153.15 & 0.16 & $\begin{array}{c}\text { Weak } \\
\text { decoupling }\end{array}$ \\
\hline 1997 & 12.92 & 157.51 & 0.08 & $\begin{array}{c}\text { Weak } \\
\text { decoupling }\end{array}$ \\
\hline 1998 & 37.83 & 160.46 & 0.24 & $\begin{array}{c}\text { Weak } \\
\text { decoupling }\end{array}$ \\
\hline 1999 & 9.99 & 160.64 & 0.06 & $\begin{array}{c}\text { Weak } \\
\text { decoupling }\end{array}$ \\
\hline 2001 & -2.79 & 186.73 & -0.01 & $\begin{array}{c}\text { Strong } \\
\text { decoupling }\end{array}$ \\
\hline 2002 & 7.17 & 194.24 & 0.04 & $\begin{array}{c}\text { Weak } \\
\text { decoupling }\end{array}$ \\
\hline 2003 & 9.24 & 211.53 & 0.04 & $\begin{array}{c}\text { Weak } \\
\text { decoupling }\end{array}$ \\
\hline 2004 & 12.97 & 213.54 & 0.06 & $\begin{array}{c}\text { Weak } \\
\text { decoupling }\end{array}$ \\
\hline 2005 & 18.53 & 194.02 & 0.10 & $\begin{array}{c}\text { Weak } \\
\text { decoupling }\end{array}$ \\
\hline 2006 & 13.91 & 198.58 & 0.07 & $\begin{array}{c}\text { Weak } \\
\text { decoupling }\end{array}$ \\
\hline 2007 & 30.36 & 222.47 & 0.14 & $\begin{array}{c}\text { Weak } \\
\text { decoupling }\end{array}$ \\
\hline 2008 & 40.54 & 253.14 & 0.16 & $\begin{array}{c}\text { Weak } \\
\text { decoupling }\end{array}$ \\
\hline 2009 & 41.88 & 256.70 & 0.16 & $\begin{array}{c}\text { Weak } \\
\text { decoupling }\end{array}$ \\
\hline 2010 & 43.27 & 261.59 & 0.17 & $\begin{array}{c}\text { Weak } \\
\text { decoupling } \\
\end{array}$ \\
\hline 2011 & 85.86 & 296.30 & 0.29 & $\begin{array}{c}\text { Weak } \\
\text { decoupling }\end{array}$ \\
\hline 2013 & 54.28 & 307.51 & 0.18 & $\begin{array}{c}\text { Weak } \\
\text { decoupling }\end{array}$ \\
\hline
\end{tabular}

The growth rates of agricultural production value and agro-emission with fixed year of 1992 were computed to examine the relationship between agricultural GDP and agro-emission. Following the definition proposed by Tapio [11], the growth rate of emission, agricultural GDP, and decoupling elasticity are calculated in the Table 2 . The total agro-emissions changes within $30 \%$ during the time period of 1992-2007, and reaches to highest record in 2011, increased by $80 \%$ compared to that of 1992 , while the reasons about big decline in 2001 and dramatic increase in 2011 need for further investigation. The agro-GDP increases continuously during the time period of 1992-2013, and there are several jumps in 1994-1995, 1999-2001, 2006-2007 and 2010-2011, but no obvious correlation has been found between the increase in agricultural GDP and the increase in agro-emission. The decoupling elasticity between agricultural GDP and agro-emission is calculated, in Table 3, and ranges from -0.01 to 0.29 , suggesting that agricultural economic growth is weakly decoupled with agro-emission, and agricultural economic development is not at cost of environmental quality in term of carbon emission generated from agricultural activities in Shanghai suburb.

\subsection{Estimation Results}

The agricultural GDP collected from Shanghai rural statistical yearbook [reference], and total agro-emission calculated for each suburb for 1993-2013 are used for regression analysis on equation (2). There are total 162 observations from nine suburbs for eighteen years and ordinary least squared method using panel data is employed to estimate the coefficients in Stata13.0, and estimation results are reported in Table 4.

Table 4. EKC model estimation

\begin{tabular}{|c|c|c|c|}
\hline Variable & Coefficient & Standard Error & $\mathrm{P}>\mathrm{t}$ \\
\hline AgGDP & $1.25^{*}$ & 0.08583 & 0.000 \\
\hline $\mathrm{AgGDP}^{2}$ & $-0.0045^{* * *}$ & 0.001054 & 0.000 \\
\hline Constant & $2.31^{*}$ & 1.3675 & 0.093 \\
\hline
\end{tabular}

Note: ***, and $* * *$ correspond to $10 \%, 5 \%$ and $1 \%$ significant level respectively.

Since both coefficients are found to be statistically significant, the agro-emission does have inverse-U shape relationship with agricultural development. The estimation results also suggest that agro-emission is weakly decoupled with agricultural development in Shanghai, which is consistent with the result from decoupling elasticity analysis in Table 3.

\section{Discussion}

Based on the analysis and computation, (1) vertical comparison in time series: total agro-emission tends to increase for the time period of 1992-2013, the annual geometric growth rate of which is $9.1 \%$ on average; the 
agro-emission intensity in term of tons of CO2eq per 10,000 RMB of agricultural GDP, decreases over the last two decades, dropping from 2.5 tons in 1992 to 0.95 tons of CO2-eq in 2013; (2) horizontal comparison cross regions: the calculation in 2013 shows that there are great differences cross different suburbs in term of total agro-emission, net emission and per capita emission. From high to low, PU, CHO, and FREN ranks top three in total emissions, when plants photosynthesis and soil absorption are taken into consideration as the channels for emission abatement, PU, FEN and $\mathrm{CHO}$ ranks top three in net emission; PU, JIN and SON lists on top three in per capita emission when population lives in each suburb is used for the calculation; (3) the results of decoupling elasticity and EKC type model indicate that growth rate of agricultural economic development is higher than that of agro-emission for the time period of 1993-2013, using 1992 as a baseline year, and the agro-emission is weakly decoupled with agricultural GDP, implying that agricultural economic development in Shanghai suburb is still in good status in term of the relationship between economic development and environmental quality (here refer to the carbon emissions generated from agricultural activities).

From the perspective of controlling total agro-emission, PU, CHO and FEN are the main regions, which play important role not only in agricultural production, but also for further emission abatement; from the purpose of controlling per capita emission, FEN, JIN and SON are the main regions, especially for JIN and SON, the per capital levels are relatively high, compared to their total emission levels in Shanghai suburbs. We suggest reducing the per capita emission from improving the use of agricultural machinery, and increasing agricultural labor productivity.

From the perspective of emission abatement, since agro-emission generated from energy consumption accounts for $58 \%$ of total agro-emissions, the improvement of energy efficiency, such as increasing the proportion of clean energy in total energy consumption in agriculture, and improving the efficiency in energy use, are the possible ways for abatement,. In the development of agricultural modernization the use of agricultural inputs becomes the second biggest source for generation of agro-emission. For instance, the fertilizer application in Shanghai agriculture is about $522 \mathrm{~kg} / \mathrm{hm}^{2}$, which is much higher than the national level, $346 \mathrm{~kg} / \mathrm{hm}^{2}$, and far less efficient than global level in term of efficiency of fertilizer application. Therefore, further emission abatement could be done through more efficient use of agricultural input per square hectare of cropland; improving soil condition and increasing efficiency of fertilizer application.

The analysis on decoupling elasticity for 1992-2013 suggests that Shanghai agricultural development is not at the cost of environmental quality as agro-emission is weak decoupling with agricultural GDP. The estimation of EKC model also supports the idea that agro-emission and agricultural development has inverse-U shape relationship.
Next step is about how to transfer from weak decoupling to strong decoupling relationship between agricultural GDP and agro-emission, which is the key emphasis and hard work for further emission abatement and sustainable agriculture. We suggest to start with key regions for controlling total agro-emission level, the new measures are required to be developed for further abatement, and the new abatement methods needed to be designed corresponding to each suburb with different agricultural production structure. Shanghai needs to promote high efficient, energy-saving and modernized agriculture at different phases for different areas in suburb.

\section{Acknowledgements}

The author is very grateful to the participants for their constructive suggestions to improve the paper at the conference of 2015 East Asia Association of Environmental and Resource Economics on August 5-7, 2015 in Taipei.

The paper is funded by the College of Economics \& Management of Shanghai Ocean University in 2015.

\section{REFERENCES}

[1] World Bank. World Development Indicators: Agricultural Methane Emissions, Online available from: http://data.world bank.org/indicator/EN.ATM.METH.KT.CE.

[2] World bank. World Development Indicators: Agricultural nitrous oxide emissions, Online available from: http://data.w orldbank.org/indicator/EN.ATM.NOXE.AG.ZS

[3] Intergovernmental Panel on Climate Change, IPCC Guidelines for National Greenhouse Gas Inventories, Institution for Global Environmental Strategies, Japan, 2006.

[4] H. Dong, Y. Li, X. Tao, X. Peng, N. Li, Z. Zhu. Chinese Greenhouse Gas Emissions from Agriculture and Its Mitigation Strategy, Transactions of the CSAE, Vol.24, No.10, 269-73, 2008. (In Chinese)

[5] B. Li, J. Zhang, H. Li, Research on Spatial-Temporal Characteristics and Affecting Factors Decomposition of Agricultural Carbon Emissions in China, China population, Resource and Environment,Vol.21,No.8,80-86,2011.(In Chinese)

[6] F. Lu, Y. Zhang, X. Qin, Z. Chen and G. Wang. Spatial analysis on carbon emission source cross regions at provincial level in China. Progress in Geography,Vol.32, No.12:1751-1759,2013 (In Chinese)

[7] X. Wu, J. Zhang, Y. Tian, P. Li. Provincial Agricultural Carbon Emissions in China: Calculation, Performance Change and Influencing Factors --using DEA-Malmquist index decomposition and Tobit model. Resource Science,Vol.36,No.1:129-138,2014 (In Chinese)

[8] Z. Huang, S. Mi. Study on Footprint of Agricultural Carbon Emission: A Case Study of Zhejiang Province, Agricultural Economics Issue, Vol.32, No.11, 40-47, 2011. (In Chinese) 
[9] X. Qian. Spatial-Temporal Variation and Impact Factor of Carbon Source and Sink of Farmland Ecosystem in Shanghai, China, Journal of Agro-Environment Science, Vol.30, No.2, 1460-67, 2011. (In Chinese)

[10] P. Tapio. Towards a Theory of Decoupling Degrees of Decoupling in the EU and the case of Road Traffic in Finland between 1970 and 2001, Transport policy, Vol.32, No.3, 110-16, 2005. (In Chinese)

[11] K. Yuan, J. Dong. Carbon Emissions in Hubei: Calculation, Structure and Decoupling Elasticity, Research of Agricultural Moderization, Vol.35, No.4, 397-402, 2014. (In Chinese)

[12] National Development and Reform, Emission factors for Regional Power Grid in China in 2014, online available from: http://www.chinapower.com.cn/newsarticle/1102/new11021 72(In Chinese)

[13] R. Zhang, M. Wang, J. Li, X. Yang, X. Wang, The Present Status of Emission Methane in China. Climatic and Environmental Research, Vol. 4, No.2, 194-202, 1999. (In Chinese)

[14] T. O. West, G. Marland. A Synthesis of Carbon Sequestration, Carbon Emissions and Net Carbon Flux in Agriculture: Comparing Tillage Practice in the United States. Agriculture
Ecosystem \& Environmental Science \& Technology, Vol.91,No.1, 217-232,2002.

[15] Institution of Agricultural Resource and Environmental Ecology of Nanjing Agricultural University, 2010's Annual Report, Online available from: http://www.guandang.net/pdf /888351.html. (In Chinese).

[16] Y. Tang, Y. Lin. Analysis on the Present Situation of Chemical Fertilizer Application and Grain Yields in Shanghai. Acta Agriculture Shanghai, Vol. 29, No. 4, 112-114, 2013. (In Chinese)

[17] Q. Cao, G. Mao, Y. Wu. Study on Characteristics and Tendency of Chemical Fertilizer Applied to Farmland in Shanghai Suburbs. Acta Agriculturae Shanghai, Vol. 24, No.4, 20-24, 2008. (In Chinese)

[18] F. Zhang, J. Wang, W. Zhang, Z. Cui, W. Ma, X. Chen, R. Jiang, Nutrient Use Efficiencies for Major Cereal Crops in China and Measures for Improvement, Acta Pedalogica Sinica, Vol. 45, No. 5, 916-24,2008. (In Chinese)

[19] Shanghai Committee of Agriculture, Shanghai Rural Statistics Yearbook, Shanghai Bureau of Statistics, China, 1993-2014. (In Chinese)

[20] National Bureau of Statistics, Statistics of New China 's Sixty years, China Statistics Press, Beijing, 2009. (In Chinese) 